\title{
Eredu aurresaleetako aldagai jarraituen kategorizaziorik hoberena lortzeko metodologia proposamena: aplikazio zehatza medikuntzan
}

\author{
Irantzu Barrio $^{* 1,3}$, Inmaculada Arostegui ${ }^{1,3}$, Susana Garcia-Gutierrez ${ }^{2,3}$ \\ ${ }^{1}$ Matematika Aplikatua, Estatistika eta Ikerkuntza Operatiboa Saila. \\ Euskal Herriko Unibertsitatea (UPV/EHU) \\ ${ }^{2}$ Ikerkuntza Unitatea, Galdakao-Usansolo Ospitalea \\ ${ }^{3}$ Red de Investigacion en Servicios de Salud \\ en Enfermedades Cronicas (REDISSEC) \\ *irantzu.barrio@ehu.es
}

Laburpena: Medikuntzan parametro kliniko asko kategorizatzen dira erabaki prozesuak errazteko. Areago arau aurresale klinikoen garapenean ohiko teknika bat da aldagaien kategorizazio hau. Aldagai aurresale bat kategorizatzerakoan kategoria kopurua aldagai aurresale eta erantzulearen arteko erlazioaren menpe dagoenez bi kategoria baino gehiagoren beharra aztertu behar da. Guk metodo bat proposatzen dugu aldagai aurresaleak kategorizatzeko eredu aurresaleetan: eredutik lortutako funtzio leunaren arabera gutxienez batez besteko arriskuko kategoria bat eta arrisku altu eta arrisku baxuko behar beste kategoriak sortzea. Metodologia hau bihotz-gutxiegitasun desorekatu larria duten pazienteen kohorte prospektibo batean aplikatu dugu aldagai aurresalea arteriatentsioa eta aldagai erantzulea epe laburreko heriotza izan direlarik. Erregresio logistiko gehigarria erabili da aldagai aurresale eta erantzulearen arteko erlazioa erakusteko. Proposatutako metodoa erabiliz lortutako kategoria-aldagaia jatorrizko aldagai jarraituarekin konparatu dugu AIC eta AUC parametroak erabiliz. Lau kategorietako arteriatentsio sistolikoko proposamena honako hau da $\leq 120(120,136](136,158]$ eta $>158$. Lau kategoria horietarako $\mathrm{AIC}=344,59$ eta $\mathrm{AUC}=0,72$ balioak lortu dira. Aldagai jarraiturako AIC $=345,7$ eta $\mathrm{AUC}=0,718$ balioak lortu dira bi AUC balioen artean diferentzia adierazgarririk egon gabe $(p=0,974)$. Guk proposaturiko metodoaren bitartez aldagai jarraitua kategorizatzeko beharrezkoak diren mozketa-puntu kopurua eta puntuen kokapenik hoberena lortzen da. Horrela lortutako kategoria-aldagaiak jatorrizko aldagai jarraituak bezainbesteko errendimendu ona ematen du.

Gako hitzak: kategorizazioa; eredu aurresaleak; bihotz-gutxiegitasuna.

Abstract: In clinical practice many continuous clinical parameters are categorised for ease of decision making. Even more categorisation of continuous predictors is a 
common technique in clinical research such as for instance in the development of clinical prediction rules. Since the number of categories into which a continuous predictor must be categorised depends partly on the relationship between the predictor and the outcome the need for more than two categories must be borne in mind. We propose a categorisation methodology for clinical-prediction models using Generalised Additive Models (GAMs) with P-spline smoothers to determine the relationship between the continuous predictor and the outcome. The proposed method consists of creating at least one average-risk category along with high- and low-risk categories based on the GAM smooth function. We applied this methodology to a prospective cohort of patients with acute decompensate heart failure where the response variable was short-term mortality and the predictor variable was systolic arterial tension. We used the additive logistic regression model to show the relationship between the predictor and the response variable. The categorised variable obtained was compared to the original continuous variable by means of the AIC and AUC parameters. The four categorical version of the systolic arterial tension proposed was $\leq 120(120,136]$ $(136,158]$ and $>158$ for which $\mathrm{AIC}=344,59$ and $\mathrm{AUC}=0,72$ values were obtained. For the original continuous variable $\mathrm{AIC}=345,7$ and $\mathrm{AUC}=0,718$ values were obtained with no statistically significant differences being found between the two AUCs $(p=0,974)$. Our proposal methods provides an optimal categorisation of the original continuous variable providing best number and location of cut points. In this way the proposed categorical variable performs as successfully as the original continuous variable.

\section{Keywords:}

\section{SARRERA}

Oro har, praktika klinikoko arrazoiak direla medio, nahiko ohikoa da medikuek jasotzea eta kategoria bihurtzea funtsean jarraituak diren parametroak. Praktikan, proba klinikoen emaitzak normal, ez-ziur edo anormal modura sailkatzen dira maiz edo, bestela, emaitza horiek gaixoaren pronostikoa zehazteko larritasun eskala modura erabili ohi dira.

Izan ere, ikerketa klinikoan, normaltasun/anormaltasun printzipioan oinarritu eta aldagai jarraitu asko etengabe kategorizatzen dira, hala nola, gaixotasunaren larritasuna (ordinala). Praktika horrek ondo islatzen du medikuen pentsamendua eta haien erabaki klinikoak hartzeko prozesua eta beraz, aldagaien kategorizazioa metodo arrunta da emaitzak erabilgarri eta praktiko bihurtzeko [1], ikerketa testuinguruan. Zehazki, aldagaien kategorizazioa sarri erabiltzen da medikuntzako erabaki-prozesuan garrantzitsuak diren arau aurresale klinikoen (AAK) garapenean. AAK asko eredu estatistikoetan oinarritzen dira, zenbait aldagai kliniko aldagai aurresale potentzialtzat hartuta. Ereduak ohiko praktika klinikoan aplikatzea denean helburu, aldagai erantzule eta aurresaleen definizioek eta praktikan erabiltzen direnek bat etorri behar dute [2]. Areago, aldagai aurresale eta erantzulearen arteko erlazioak zein aldagai aurresalearen probabilitate-banaketak baldintzatu dezakete aldagai aurresaleak eredu estatistikoan duen eragina. Ondo- 
rioz, azken ereduaren doikuntza-egokitasuna eta errendimendua hiru ezaugarri nagusiren menpe dago: (1) aldagaien definizio on eta praktiko baten hautua, (2) aldagai aurresale eta erantzulearen arteko erlazioaren neurketa egokia eta (3) aldagai askeek ereduan duten indarra. Ongi dokumentatuta dago estatistikaren ikuspuntutik, hobe dela eredu estatistikoa aldagai jarraituen bidez garatzea, aldagaien kategorizazioak informazioaren eta ereduaren indarraren galera ekar baitezake [3]. Edonola ere, ikuspegi praktiko batetik, aldagai jarraituak ez dira sarri erabiltzen AAKen garapenean [4]. $\mathrm{Bi}$ arrazoi nagusi daude hori horrela izateko. Lehenengo eta behin, frogatu behar da aldagai jarraitu bat ereduan sartzeko, aldagai erantzulearen eta aldagai askearen arteko erlazio linealaren hipotesia betetzen dela eta, askotan, hori ez da betetzen. Beraz, analisi estatistikoa bera erronka metodologiko bihur daiteke. Bigarrenik, praktika klinikoaren ispilutzat har daiteke kategorizazioa. Ikerkuntza klinikoaren bidez lortutako emaitzak garrantzitsuak ohi dira praktika klinikoaren garapenean eta, azken horretan, erabakiak kategorikoak dira berez. Ondorioz, kategoria-aldagaien bidez sortutako ereduak ulergarriagoak dira medikuentzat eta errazago erabil daitezke erabaki prozesuetan. Zenbaitetan, markatzaile jarraitu batetik abiatutako irizpide klinikoetan oinarrituta daude erabaki horiek. Horietan, mozketa puntu bat, edo gehiago, paziente batek gaixotasunen bat edo egoera zehatzen bat duenentz erabakitzeko aukeratzen dira. Irizpide horiek zeharo ezberdinak izan daitezke medikuen, ospitaleen edota herrialdeen artean. Esaterako, Limek eta Kellyk egindako meta-analisi batek erakutsi zuen hiperkapnia dagoela ondorioztatzeko, PCO2aren (karbono dioxidoaren odoleko presio partziala) mozketa puntuak 30 eta $46 \mathrm{mmHg}$ tartean daudela [5]. Beraz, AAKen garapenean gai garrantzitsua da aldagai kliniko jarraituen kategorizazio egokiaren bilaketa.

Aldagai jarraituen kategorizazioaren inguruan beste lan batzuk ere argitaratu dira. Aldagaiak kategorizatzeko metodoen berrikuspen batean, adibidez, metodoak bi taldeetan sailkatuak agertzen dira [4]: a) grafiko esploratzaileak eta b) p-balio minimoaren hurbilketa. Grafiko esploratzaileei dagokienez, aldagai jarraituak bitan kategorizatzeko, hau da, dikotomizatzeko, Hin et al-ek proposatu zuten eredu gehigarri orokortuan (GAM izenekoan) oinarritutako metodoa [6].

Aldagai jarraitua zenbat kategoriatan banatzea aldagai erantzulearen eta aldagai aurresalearen arteko erlazio grafiko eta zenbakizkoaren menpekoa izango da, besteak beste. Beraz, kontuan izan behar da bi kategoria baino gehiago sortzearen beharra. Adibidez, odolaren presioa bezalako aldagaiak kategorizatzerakoan, ez da posible mozketa puntu bakarra erabiltzea gaixoaren arrisku handia eta txikia sailkatzeko, balio handiak eta balio txikiak arrisku handiagoarekin lotuta baitaude [7]. Are gehiago, lan batek kritikatu egiten ditu [8] aldagaiak kategorizatzeko sarritan eta era arbitrarioan erabiltzen diren kuantilak, epidemiologia ikerkuntzan. Lite- 
raturan aho batez onartzen da ezen aldagai aurresaleen kategorizazioak ondo argudiatua eta motibatua egon behar duela eta, beharrezkoa izanez gero, mozketa puntuak aurkitzeko metodoak objektiboa eta ongi balioztatua izan behar duela.

Lan honen helburua honako hau da: gure proposamena azaltzea aldagai aurresale jarraituen kategorizaziorako, AAKetan erabiltzeko; horretarako, kategoria kopuru zein mozketa puntu egokienen bilaketa prozesua azalduko dugu. Proposatutako metodoaren abiapuntua hauxe da: aztertzea, GAM erabiliz, aldagai jarraituaren eta aurretiaz definitutako aldagai erantzule adierazgarri baten arteko erlazioa. Horri esker, aukeratutako aldagai erantzulearen aurresatean jarriko dugu arreta, aldagai aurresaleari dagozkion mozketa puntuak aukeratuz eta beharrezkoak diren kategoriak sortuz. Proposaturiko kategorizazio metodoak kontuan hartzen du aldagai erantzule eta aldagai askearen arteko erlazio funtzionala. Horrela, ziurra da aldagai jarraitutik ez dela informazio kritikorik galtzen. Are gehiago, lortutako kategorizazioa praktika klinikoaren ikuspuntutik erabilgarri izatea dugu helburu, aurresateko gaitasuna eta errutinazko praktika klinikoan erabilgarritasuna uztartuz. Proposaturiko metodoa bihotz-gutxiegitasuneko ikerketa bateko datu errealak aztertzeko erabili da eta beste metodo batzuen bidez lortutako emaitzekin alderatu da.

Hemen aurkezten dugun lana hiru atal nagusitan banatuta dago. Metodoak atalean, GAMari buruzko teoria eta proposaturiko metodoa azaltzen dira. Gainera, atal horretan, proposaturiko metodologia aplikatu eta balioztatuko den bihotz-gutxiegitasuneko ikerketa azaltzeaz gain, zehaztasunez azaltzen dira balioztapenerako erabiltzen diren metodoak. Emaitzak atalean, proposaturiko metodoaren bidez datu errealak aztertzean lortutako emaitzak aurkezten dira, balioztapen prozesuaz gain. Azkenik, lan hau eztabaida eta ondorio batzuekin bukatuko da.

\section{METODOAK}

Metodoen atala bi azpiataletan banatuta dago. Lehenengoan, metodologiaren teori ikuspegiak azaltzen dira eta GAMaren sarrera labur bat ere biltzen da, proposaturiko metodologia ulerterrazagoa egiteko asmoz. Bigarrenean, proposaturiko metodologia datu errealak aztertzeko metodoetan arreta jartzen da eta, gainera, proposaturiko metodologia balioztatzeko erabili diren irizpideak ere azaltzen dira.

\section{Metodo teorikoak}

Eredu Gehigarri Orokortua (GAM) da Eredu Lineal Orokortuaren (GLM) hedadura [9], non aurresale linealaren zati bat aldagai azaltzaileen 
funtzio leunen batura bezala adierazten den. Orokorrean, aldagai erantzulea normala ez denean, ondoko egitura du ereduak:

$$
g(\mu)=\alpha_{0}+\sum_{i=1}^{p} f_{i}\left(X_{i}\right)
$$

adierazpen horretan $\mu$ da $\mu=E(Y)$, hots $Y$ familia esponentzialaren banaketa duen aldagai erantzulea, $g$ esteka funtzioa eta, $f_{i} X_{i}$ aldagai azaltzaileen gaineko funtzio leunak, edozein $i=1, \ldots, p$-tarako.

GAM ereduak GLM ereduak baino malgutasun handiagoa eskaintzen du, aldagai erantzulerako itxarotako balioa eta aldagai azaltzaileen arteko menpekotasun linealaren hipotesia erlaxatzen duelako. $f_{i}$ funtzio leunen estimazioa da GAMek daukan zailtasunik handiena. Eragozpen horri aurre egiteko badira hainbat aukera. Ohiko hautabideak splineetan oinarrituta daude, horiek GAMaren estimazioa GLMaren testuingurura murriztea bermatzen dute [10]. Splineak dira zatikako polinomioak, nodo izeneko puntuetan elkartzen direnak, izan ere. Bi familia nagusi daude eredu leuntzaile horietan: (1) erregresio-splineak eta (2) spline leuntzaileak. Erregresiospline ereduan, nodo kopurua eta kokapena hautatu egiten dira, beti ere, nodo horietan zatikako polinomioak leunki biltzen direlarik. Aldiz, spline leuntzaileek nodo kopuru finkoa erabiltzen dute [11]. Alegia, spline honek, $X$ aldagaiak bezainbesteko balioak hartzen ditu eta ereduaren leuntasuna karratu txikienen doikuntzan penalizazio bat gehituz kontrolatzen du. Funtzio leunak sortzeko erdibidea da penalizatutako spline delakoa erabiltzea. Eilersek eta Marxek [12] aurkeztu zuten azken hori, P-spline deritzona. Penalizatutako splineek aurreko bien abantailak biltzen dituzte. Spline leuntzaileek baino nodo gutxiago erabiltzen dituzte P-splineek eta nodoen kokapenaren garrantziak behera egiten du, zimurtasun-zigor orokorragoak ezartzen baitituzte.

Guk geuk ikusmiran daukagu aldagai jarraituak kategorizatzea, P-spline leuntzaile eta GAM ereduak erabiliz. Orokortasuna galdu gabe, demagun $X$ aldagai jarraitua kategorizatu nahi dugula eta, berebat, $Y$ familia esponentzialaren banaketa duen aldagai erantzulea daukagula. ( $X$ aldagaia kategorizatuko dugu $Y$ aldagai erantzulean daukan eraginean oinarrituta). Kasu horretan, (1)-en definitutako GAM eredua doitu egiten da, $X$ eta $Y$ hurrenez hurren aldagai azaltzaile eta aldagai erantzulea izanda.

$$
g(\mu)=\alpha_{0}+f(X)
$$

Adierazpen horretan, $g$ esteka funtzioa eta $\mu, \mu=E(Y)$ dira.

GAM eredua doitzerakoan $X$ eta $f(X)$-ren arteko erlazio grafikoa lortzen da. Grafikoan, $X$ aldagaia ardatz horizontalean agertzen da eta $f$ funtzio leuna, ardatz bertikalean. Batezbesteko funtzio zentratua da $f(X)$. 
Zentro-koefizientea $\alpha_{0}$ da, hau da, $X$ aldagaiaren batezbestekoa adierazten du. Aldagai jarraitua kategorizatzeko kategoria kopurua bai eta mozketa puntuen kokapena grafiko honetan oinarrituta aukeratuko ditugu. Beraz, hauxe proposatzen dugu: batez besteko arriskuko puntu horren inguruan batez besteko arriskuko kategoria sortzea eta, berebat, sortzea era berean $X$ eta $f(X)$ funtzioaren arteko erlazioa ondo biltzeko arrisku handiko eta arrisku txikiko behar besteko kategoriak ere.

Batez besteko arriskuko kategoria sortzeko metodologia xehetasunez azaltzen da Barrio et al-en lanean [13]. Hala ere, aurrekoaren laburpen txiki bat eskainiko dugu jarraian.

Batez besteko arriskuko kategoria definitu dela, bi egoera posible hartuko ditugu aintzakotzat, arrisku handiko eta txikiko kategoriak definitzeko: 1) GAM ereduaren bitartez lortutako aldagai azaltzaile eta erantzulearen arteko erlazio grafikoa lineala da $X$-ren barruti osoan eta 2) erlazio hori ez da lineala, hau da, jauzia edo malda-aldaketa gertatzen da. Lehenengo egoeran, proposatzen dugu gutxienez 3 kategoriatan $X$ kategorizatzea. Kategorizazio horretan, kategoriak sortzeko mozketa puntuak batez besteko arriskuko kategoriaren limiteak dira. Bigarren egoeran aldiz, lehendabizi hasierako hiru kategoriak sortzea proposatzen dugu: arrisku txikia, batez besteko arriskua eta arrisku handia deiturikoak. Bigarrenik, maldaaldaketak gertatzen diren puntuak hartuko dira aparteko ebaki-puntutzat. Ondorioz, dagokien arrisku txikiko edo arrisku handiko kategoriak edo biak, berriz kategorizatuko dira: oso txiki eta txiki edo oso handi eta handi modura, hurrenez hurren. Mozketa puntu horien hautua grafikoaren maldan eta esangura klinikoan oinarrituko da.

Kasu bietan, proposaturiko gutxieneko hiru kategoria baino gehiagoren beharra ebaluatzea proposatzen da eta, baldin eta kategoria gehiago sortzen badira, lortutako emaitzak hasierako aldagai jarraituarekin konparatuko dira. Balioztatze-irizpidea zehaztasunez azaltzen da jarraian.

\section{Metodoaren aplikazioa}

Aldagai jarraituak kategorizatzeko metodologia hau, Estatuko 3 ospitaletako larrialdi-zerbitzuetara bertaratutako bihotz-gutxiegitasun desorekatu larria (BGDL) duten 1282 pazienteren kohorte prospektiboa aztertzeko erabili da. Ikerketa honetan, datuak bi unetan jaso ziren: lehendabizi pazienteak larrialdi-zerbitzuan ebaluatu zirenean eta azkenik pazientea ospitaleratua izan bazen ospitaleratze-unean eta pazienteari larrialdi-zerbitzuan sendagiria eman bazitzaion, sendagiria eman eta zazpi egunera. Bildutako datu nagusiak, bihotz-gutxiegitasunarekin uztartu ziren: NYHA disnea eskalaren bitartez neurtutako larrialdi-zerbitzura heltzerako egoera funtzionala, test kliniko eta osagarrietan oinarritutako pazientearen egoera klinikoa (EKG, erradiografia, parametro klinikoak proBNP eta TnT barne) eta 
beste gaixotasun batzuen presentzia eta arrisku kardiobaskularra adieraz dezaketen faktoreak.

Ohiko egoera larria da BGDL delakoa, larrialdi-zerbitzuetan, eta horrelakoetan oso garrantzitsua da erabakiak hartzeko tresna eta parametro egokiak izatea pronostikoa eta premiazkoak diren tratamenduak ezartzeko. Oinarrizko parametro horien artean, NYHA eskala, bihotz-maiztasuna eta arteria-tentsio sistolikoa (TAS) dira besteak beste garrantzitsuenetariko batzuk. Horrenbestez, kasu honetan, TAS aldagaia kategorizatzea izan da helburua. Horretarako, TAS eta heriotzaren arteko erlazio grafikoa aztertu dugu P-spline leuntzailea eta GAM eredua erabiliz.

Aukeratutako aldagai erantzulea dikotomikoa denez gero, GAM ereduan erabilitako esteka funtzioa logit funtzioa izan da. Kasu horretan, (2) ekuazioan deskribatutako eredua $X$ aldagai bakarrerako, ondoko adierazpenaren bitartez zehaztuta egongo litzateke:

$$
\operatorname{logit}(p)=\alpha_{0}+f(X)
$$

Adierazpen horretan, $p$ da $Y=1$ betetzeko probabilitatea, hau da, paziente batek hiltzeko duen probabilitatea.

Metodoa balioztatzeko, proposatutako kategoria-aldagaiaren errendimendua hasierako aldagaiarenarekin konparatu dugu. Gainera, proposatutako kategorizazioa Hin et al-ek (1999) [6] proposaturiko aldagai dikotomikoarekin alderatzen dugu.

Ereduak konparatzeko irizpide bi hautatu ditugu. Lehenengoa, Akaike Information Criterion (AIC) da, oso ezaguna den metodo klasikoa. Bigarrena, aldiz, honako bi hauetan oinarrituta dago: (3) ekuazioan definitutako eredu espezifikoan eta ikerketaren helburuetan. Kasu jakin horretan, aukeratutako ereduak aurresateko duen gaitasuna ebaluatzea da gure helburu. Ondorioz, erregresio logistikoaren aurresateko gaitasuna kuantifikatzen duen parametro modura aukeratu dugu Receiver Operating Characteristic (ROC) kurbaren azpiko azalera (AUC, Area Under the Curve). Bi ROC kurben AUC parametroak konparatzeko, DeLong testa erabili dugu [14].

Bestalde, proposatutako kategorizazioaren doikuntza-egokitasuna HosmerLemeshow testaren bitartez ebaluatu da. Izan ere, test horrek ebaluatzen du eredu logistikoan behatutako gertaeraren eta itxarotako gertaeraren arteko komunztadura [15]. Azkenik, hiru kategoria baino gehiagoren beharra ere egiaztatzen dugu, kategoria osagarria eta bere ondokoaren arteko arriskudiferentziak estatistikoki ebaluatuz.

Analisi estatistiko guztiak R programa erabiliz egin dira. Programa horren mgcv, BB eta pROC libreriak erabili izan dira, GAM eredua, mozketa puntuak eta AUC balioak kalkulatzeko, hurrenez hurren. 


\section{EMAITZAK}

\section{Kategorien sormena}

1. irudian agertzen da TAS eta heriotzaren arteko erlazioa deskribatzen duen P-splineekin doitutako GAM eredua. Ikus daitekeenez, bi aldagaien arteko erlazioa lineala da eta balio bakarra dago, $x_{0}=145$, zeinak $f\left(x_{0}\right)=0$ betetzen baitu. Metodoaren bidez lortutako batez besteko arriskuko kategoria $(132,158)$ da. Beraz, TAS hiru kategoriatan sailkatzen da, eta heriotza izateko arrisku handia dago 132 baino balio txikiagoetan eta arrisku txikia 158 baino balio handiagoetan. Horrenbestez, TAS delakoa hiru kategorietan sailkatzeko gure proposamena hauxe da: $\leq 132,(132,158],>158$.

Jatorrizko ereduarekiko doikuntza optimoa lortzeko asmoz, laugarren kategoria baten beharra aztertu da. Kasu horretan, irizpide klinikoetan oinarritu da mozketa puntu gehigarriaren hautaketa [16]. Pazienteen $\% 5$ baino gutxiago 100 baliotik baino beheragoetan dagoenez, tarte horretako balioak baztertu egin dira, hots, 100 baliotik beherakoak. Ondorioz, hautatutako hirugarren mozketa puntua 120 izan da (ikus 1 . irudia). Horrela, ondoko lau kategoriako TAS aldagaia ebaluatu da: $\leq 120,(120,132],(132,158],>158$.

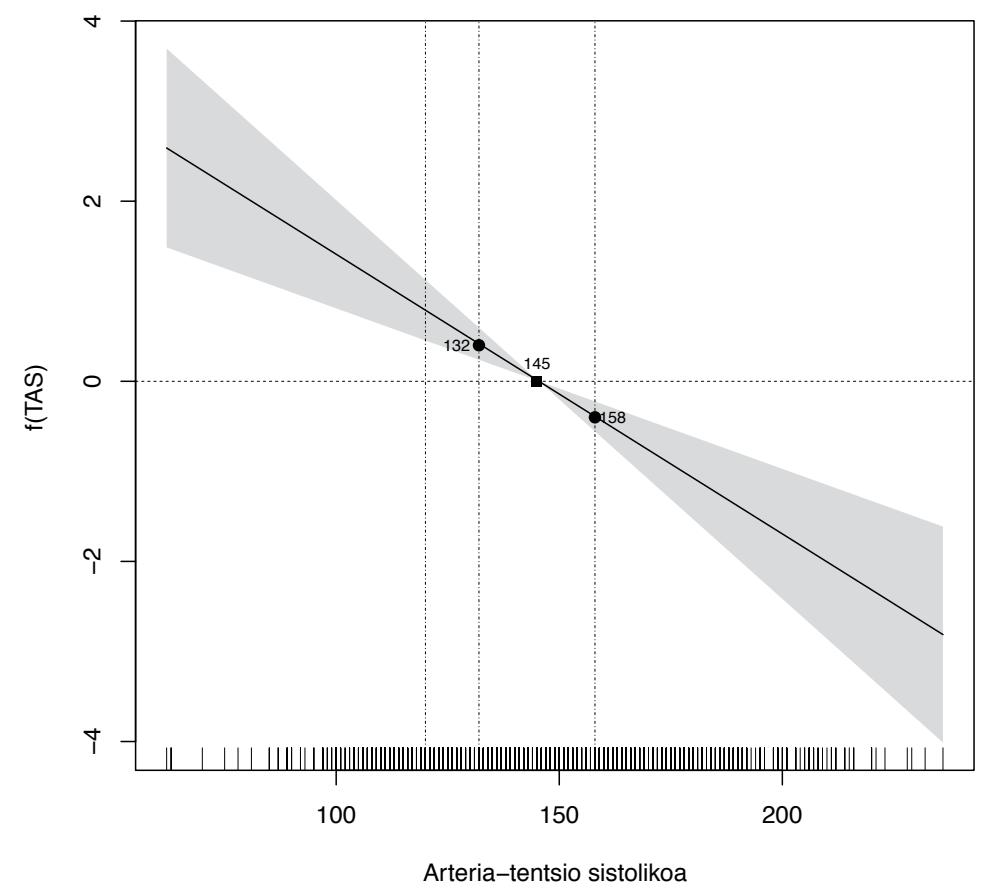

I. irudia. Arteria-tentsio sistolikorako lortutako mozketa puntuen irudikapen grafikoa. 
Horrez gain, TAS aldagaia, lehenago esan dugunez, dikotomizatu egin da. Dikotomizazioan, mozketa puntuaren balioa 145 izan da: hiltzeko batez besteko arriskuko balioa. Ondorioz, bi kategoriako TAS aldagaiaren proposamena honako hau da: $\leq 145,>145$.

\section{Balioztatzea}

Aurresale jarraituarekin lortutako AIC eta AUC parametroak aukerarik hoberentzat hartu ditugu eta aldagai dikotomikoarekin lortutakoak, aldiz, hobetzeko aukeratzat. 1. taulan ikus daitezke balioztatze prozesuaren emaitza zehatzak.

1. taula. Proposaturiko metodologian oinarritutako arteria-tentsio sistolikoaren kategorizazioa.

\begin{tabular}{|c|c|c|c|c|c|c|}
\hline Aldagaia & \multicolumn{2}{|c|}{ Mozketa puntuak } & Lagin tamaina & AIC & AUC & p-balioa* \\
\hline TAS & Jarraikia & & 1233 & 345,73 & 0,718 & - \\
\hline TAS & Dikotomikoa & $\begin{array}{l}\leq 145 \\
>145\end{array}$ & $\begin{array}{l}654 \\
579\end{array}$ & 360,52 & 0,620 & 0,06 \\
\hline TAS & 3 kategoria & $\begin{array}{c}\leq 132 \\
(132-158] \\
>158\end{array}$ & $\begin{array}{l}425 \\
413 \\
395\end{array}$ & 351,30 & 0,690 & 0,594 \\
\hline TAS & 4 kategoria & $\begin{array}{c}\leq 120 \\
(120-132] \\
(132-158] \\
>158\end{array}$ & $\begin{array}{r}39 \\
386 \\
413 \\
395\end{array}$ & 344,59 & 0,720 & 0,974 \\
\hline
\end{tabular}

* DeLong's testarekin lortutako emaitza eredu bakoitzaren AUC balioa eta aldagai jarraituarekin lortutakoa alderatzerakoan.

TAS delakoa, gutxienez, hiru kategoriatan sailkatzea proposatu dugu eta, horretarako, ondoko hauek dira lortu ditugun balioak: $\mathrm{AIC}=351,3$ eta $\mathrm{AUC}=0,690$ hiru kategoriako aukerenak versus $\mathrm{AIC}=345,7$ eta $\mathrm{AUC}=0,718$ aurresale jarraituarenak, bi AUC balioen artean adierazgarritasun estatistikorik gabe $(p=0,594)$. Aurresale dikotomikoari dagozkion parametro berdinen balioak AIC $=360,5$ eta $\mathrm{AUC}=0,620$ dira. Diferentzia adierazgarriak aurkitu dira 3 kategoriako eta 2 kategoriako aldagaiak alderatutakoan $(p<0,001)$, AUC balioen artean. Baina ez, ordea, bi kategoria eta aurresale jarraitua alderatutakoan $(p=0,06)$.

Azkenik, 4 kategoriako aukerarekin $\mathrm{AIC}=344,59$ eta $\mathrm{AUC}=0,720$ balioak lortu dira. Ez da diferentzia adierazgarririk aurkitu AUC balioen 
artean, jarraituarekin alderatutakoan $(p=0,974)$, baina bai 3 kategoriakoarekin alderatutakoan $(p=0,001)$. Halaber, 4 kategoriako eredua doitzerakoan, diferentzia adierazgarriak aurkitu dira: 120 eta (120-136] kategorietan estimatutako parametroen artean $(p=0,008)$. 2. taulan aurkezten dira doitutako ereduaren emaitza zehatzak. Horrez gain, eredua ondo kalibratuta dagoela esan genezake, Hosmer-Lemeshow testaren bidez lortutako p-balioa $>0,05$ baita.

2. taula. 4 kategorietako TAS aldagaiarekin doitutako ereduko emaitzak. Beta koefizienteen estimazioak, beraien \% 95eko konfiantza tarteak eta beraien adierazgarritasunaren p-balioak agertzen dira.

\begin{tabular}{lccc}
\hline \multicolumn{1}{c}{ Kategoria } & Estimazioa & $\% 95 \mathrm{KT}$ & p-balioa \\
\hline TAS $\leq 120$ & - & - & - \\
TAS $(120-132]$ & $-1,33$ & $(-2,44,-0,42)$ & 0,008 \\
TAS $(132-158]$ & $-1,45$ & $(-2,25,-0,71)$ & $<0,001$ \\
TAS $>158$ & $-2,33$ & $(-3,57,-1,36)$ & $<0,001$ \\
\hline
\end{tabular}

Hosmer-Lemeshow testarekin lortutako p-balioa > 0,05. KT: Konfiantza Tartea.

\section{EZTABAIDA}

Praktika klinikoan, parametro klinikoetan oinarrituta hartu behar dira erabakiak eta horiek, oro har, jarraituak dira. Parametro horien eta zenbait gaixotasun garatzeko arriskuaren arteko erlazioa ezagutzeak, laguntzen du arrisku gehien duten pazienteak identifikatzen. Estatistikaren ikuspuntutik, hobe da parametro horiek jarraitutzat hartzea, kategorizazioak informazioaren galera eta ereduaren ahalmenaren galera ekar baitezake [3]. Hala ere, praktikan aplikatzea helburu duten AAKen garapenean, desiragarriagoa izaten da zenbait informazio galtzea, eguneroko praktika klinikoan ereduaren erabilgarritasun eta erraztasunaren alde.

Aipatutako datu-basearen testuinguruan eredu aurresaleen garapenean ari diren ikertzaileak, ikerketaren helbururako jasotako hainbat aldagai jarraituren kategorizazioaren beharra ikusi dute. Ikerketarako beharrezkoa den informazio guztia ez da erregistro klinikoan agertzen eta agertzen den batzuetan ez da behar bezala agertzen. Esaterako, pazientearen egoeraren deskribapen bat agertzen da sarritan, zenbakizko balio bat agertu beharrean. Are gehiago, aipatutako ikerketaren moduko egoeretan, larrialdizerbitzuetako praktika klinikoak ikerketa beharrak gailentzen ditu. Ondorioz, eskuragarri dagoen informazioa da, hain zuzen, errutinaz BGDL duten pazienteentzako larrialdi-zerbitzuan bildutako informazioa. 
Aipatutako guztia kontuan hartuta, aurresale gisa hautatutako parametro klinikoetarako kategorizazio metodo egokia izatea beharrezkoa da, betiere ondoko hiru osagaiak kontuan izanik:

1. Hautatutako aldagai erantzulearen menpekoa izango da kategorizazioa eta, ondorioz, analisiak garatzeko hautatutako ereduaren menpekoa.

2. Edozein informazio-galera minimoa izango da, jatorrizko aldagai jarraituarekin alderatuz.

3. Erosoa eta interpretaerraza den kategoria-aldagai aurresalea eskainiko zaie medikuei.

Esan bezala, aurreko lan batean proposatu dugu kategoria eta mozketa puntu hoberenak lortzeko metodologia [13]. Metodologia hori aplikatzeko, erantzulearen eta aldagai aurresalearen arteko erlazioa ezagutzea guztiz beharrezkoa da aurreko bi oinarriak bete ahal izateko. Horretarako GAM funtzioak aukeratu dira, teknika indartsua baita aurresale jarraitua eta erantzulearen arteko erlazioa estimatzeko [9]; izan ere, bi aldagai horien arteko erlazioaren gaineko inolako hipotesiren beharrik gabe. Literaturan, P-splineak gomendatzen dira funtzio leunen estimazioa egiteko [17].

Hin et al-en (1999) [6] proposamena aintzakotzat hartu dugu gure metodoaren lehen hurbilketa gisa: haien proposamena aurresale jarraitua dikotomizatzean datza. Gure ustetan, lagin tamainaren oso menpekoa izan daiteke puntu bakarra eta horren ordez, batez besteko arriskua duen kategoria bat sortzea hobea dela uste dugu. Nahiz eta tarte baten luzera ere lagin-tamainaren menpekoa izan, puntu batek baino informazio gehiago eskain diezaieke medikuei azken horrek. Bestalde, aurresale jarraituarekin konparatuz ahalik eta informazio gutxien galtzen dela ziurtatzea da gure helburuetariko bat eta, beraz, gure ustez, agian bi kategoria ez dira nahikoa.

Hin et al-ek proposaturiko aldagai dikotomikoaren eta jatorrizko aldagai jarraituaren artean kokatzen da gure proposamena. Artikulu honetan erakusten dugu ezen guk proposaturiko kategoria-aldagaiak jatorrizko aldagai jarraituaren informazio maximoa atxikitzen duela batetik, eta bestetik jatorrizko aldagai aurresale eta erantzulearen arteko erlazioa mantentzen duela. Azkenik, berebat, aplikazio zehatzaren bidez, balioztatu dugu bi kategoriako hautuak baino emaitza hobeak eskaintzen dituela, betiere aurresateko gaitasunaren ikuspuntutik begiratuta. Halaber, erakutsi dugu proposamen horrek hobetzen duela Hin et al-en proposamena, doikuntza eta aurresateko gaitasunari dagokionez. Edozein kasutan ere, 3 kategoria baino gehiagoren beharra ikertzaileek ebalua dezakete, aldagai aurresale eta erantzulearen arteko erlazioaren arabera eta lagin tamaina eta egoeraren ezagutza klinikoaren arabera ere. Are gehiago, kategoriak gehitzeak ekar dezakeen hobekuntza estatistikoki azter daiteke. Nahiz eta hemen aurkeztutakoa 
adibide adierazgarria izan, 4 kategoria aukeratu dira aipatutako TAS aldagaia kategorizatzeko.

Proposamen honen lehen muga hauxe da: proposamena bera aldagai erantzulearen menpekoa da eta beraz, ezin daiteke edozein egoeratan gomendatu. Horrek esan nahi du aldagai aurresale berbera kategorizatzeko aukera ezberdinak lor daitezkeela, aldagai erantzule ezberdinak aintzakotzat hartuz gero. Nahiz eta eredugintzaren egoera jakin batzuetan ezaugarri hori abantailatzat jo daitekeen, ezinbestekoa da kontuz berrikustea eredu ezberdinak aztertzerakoan. Gainera, aldagai aurresale bat kategorizatzeko metodoa aplika daiteke, bestelako aldagai askeak (jarraituak edo kategorikoak) ereduan aztertuz; hau da: kategorizazioa ereduari berari egokitu dakioke. Gure proposamenaren bigarren mugaketa, 3 kategoria baino gehiago behar direnean, honako honetan datza: gainerako mozketa puntuen hautuaren subjektibotasuna. Hautu hori egiteko eskema bat erakutsi dugu bi egoera hipotetikotan, eta hain zuzen horietariko bat da erakusten den aplikazioan agertzen dena.

Mozketa puntuen hautua aldagai aurresale eta erantzulearen arteko erlazio grafikoan oinarritzen da eta, ondorioz, mozketa puntu gehiago gehitzen diren heinean, kategoria-aldagaia eta jatorrizko aldagai jarraitua geroz eta antzekoagoak izango dira. Berebat, lortutako kategorizazioak geroz eta menpekotasun handiagoa izango du datuekiko. Adierazgarritasun estatistikoaz gain beraz, ikertzaileen lanaren zati garrantzitsua da praktikotasunaren eta informazio-galeraren artean oreka aurkitzea.

Laburbilduz, aurresateko eredu klinikoetan aldagai aurresale jarraituak kategorizatzeko metodoa proposatu dugu. Metodoa BGDL duten pazienteen kasuan aplikatu da eta, proposaturiko kategoria-aldagaiak jatorrizko aldagai jarraituak bezain ondo funtzionatzen duela ikusi dugu.

\section{ESKER ONAK}

Lan honen garapena posiblea izan da ondoko laguntzei esker: UE +09/62, MTM2010-14913, GIU10/21, 2012111008, IT620-13 eta UFI11/52. Datuen jazoera BIO10/ECI009 eta 2011111045 proiektuei esker izan da. Gure eskerrik beroenak ere Josu Igartuari lan honen gainean egindako errebisio sakonagatik.

\section{ERREFERENTZIAK}

[1] TURNER E., DOBSON J. eta POCOCK J. 2010. «Categorisation of continuous risk factors in epidemiological publications: a survey of current practice». Epidemiologic Perpectives \& Innovations 7, 9. 
[2] STEYERBERG E.W. 2009. Clinical Prediction Models A Practical Approach to Development, Validation and Updating. Springer, New York.

[3] ROYSTON P., ALTMAN D. eta SAUERBREI W. 2006. «Dichotomizing continupus predictors in multiple regression: a bad idea». Statistics in Medicine 25, 127-141.

[4] MAZUMDAR M. eta GLASSMAN J. 2000. «Categorizing a prognostic variable: review of methods, code for easy implementation and applications to decision-making about cancer treatments». Statistics in Medicine 19, 113-132.

[5] LIM B. eta KELLY A. 2010. «A meta-analysis on the utility of peripheral venous blood gas analyses in exacerbations of chronic obstructive pulmonary disease in the emergency department». European Journal of Emergency Medicine 17, 246-248.

[6] HIN L., LAU T., ROGERS M. eta CHANG M. 1999. «Dicotomization of continuous measurements using generalized additive modelling - application in predicting intrapartum caesarean delivery». Statistics in Medicine 18, 1101-1110.

[7] HANSSON L., ZANCHETTI A., CARRUTHERS S., DAHLOF B., ELMFELDT D., JULIUS S., MENARD J., RAHN K., WEDEL H. eta WESTERLING S. 1998. «Effects of intensive blood-pressure lowering and low-dose aspirin in patients with hypertension: principal results of the Hypertension Optimal Treatment (HOT) randomised trial». Lancet 351, 1755-1762.

[8] BENNETTE C. eta VICKERS A. 2012. «Against quantiles: categorization of continuous variables in epidemiologic research, and its discontents». BMC Medical Research Methodology 12, 211.

[9] HASTIE T. eta TIBSHIRANI R. 1990. Generalized Additive Models. Chapman \& Hall, London.

[10] CURRIE I., DURBAN M. eta EILERS P. 2006. «Generalized linear array models with applications to multidimensional smoothing». Journal of the Royal Statistical Society Series B 68, 259-280.

[11] GREEN P. eta SILVERMAN B. 1994. Nonparametric Regression and Generalized Linear Models. Chapman \& Hall, London.

[12] EILERS P. eta MARX B. 1996. «Flexible smoothing with B-splines and penalties». Statistical Science 11, 89-121.

[13] BARRIO I., AROSTEGUI I., QUINTANA J. eta IRYSS-COPD G. 2013. «Use of generalised additive models to categorise continuous variables in clinical prediction». BMC Medical Research Methodology 13, 83.

[14] DELONG E., DELONG D. eta CLARKE-PEARSON D. 1988. «Comparing the areas under two or more correlated receiver operating characteristic curves: a nonparametric approach». Biometrics 44, 837-845.

[15] HOSMER D. eta LEMESHOW S. 2000. Applied Logistic Regression. Wiley, New Jersey.

[16] O’CONNOR C.M., ABRAHAM W.T., AlBERT N.M., ClARE R., GATTIS S.W., GHEORGHIADE M., GREENBERG B.H., YANCY C.W., YOUNG J.B. eta FONAROW G.C. 2008. «Predictors of mortality after dis- 
charge in patients hospitalized with heart failure: an analysis from the Organized Program to Initiate Lifesaving Treatment in Hospitalized Patients with Heart Failure (OPTIMIZE-HF)». The Amercian Heart Journal 156(4), 662-673.

[17] RICE J. eta WU C. 2001. «Nonparametric mixed effects models for unequally sample noisy curves». Biometrics 57, 253-259. 